\title{
Demolition and Removal of Plutonium-Contaminated Facilities at Hanford
}

\author{
M. N. Raile
}

May 1975

Prepared for the U. S. Energy Research and Development Administration

Under Contract AT(45-1)-2130

Atlantic Richfield Hanford Company

Richland, Washington 99352

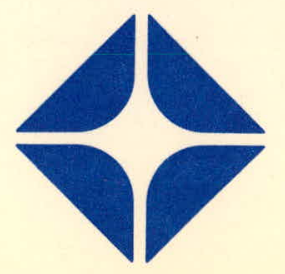




\section{DISCLAIMER}

This report was prepared as an account of work sponsored by an agency of the United States Government. Neither the United States Government nor any agency Thereof, nor any of their employees, makes any warranty, express or implied, or assumes any legal liability or responsibility for the accuracy, completeness, or usefulness of any information, apparatus, product, or process disclosed, or represents that its use would not infringe privately owned rights. Reference herein to any specific commercial product, process, or service by trade name, trademark, manufacturer, or otherwise does not necessarily constitute or imply its endorsement, recommendation, or favoring by the United States Government or any agency thereof. The views and opinions of authors expressed herein do not necessarily state or reflect those of the United States Government or any agency thereof. 


\section{DISCLAIMER}

Portions of this document may be illegible in electronic image products. Images are produced from the best available original document. 


\section{Atlantic Richfield Hanford Company \\ Richland, Washington 99352}

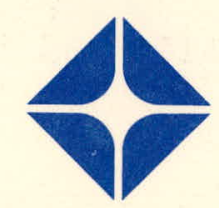

NOTICE

THIS REPORT WAS PREPARED AS AN ACCOUNT OF WORK SPONSORED BY THE UNITED STATES GOVERNMENT. NEITHER THE UNITED STATES NOR THE UNITED STATES ENERGY RESEARCH AND DEVELOPMENT ADMINISTRATION, NOR ANY OF THEIR EMPLOYEES, NOR ANY OF THEIR CONTRACTORS, SUBCONTRACTORS, OR THEIR EMPLOYEES, MAKES ANY WARRANTY, EXPRESS OR IMPLIED, OR ASSUMES ANY LEGAL LIABILITY OR RESPONSIBILITY FOR THE ACCURACY, COMPLETENESS, OR USEFULNESS OF ANY INFORMATION, APPARATUS, PRODUCT OR PROCESS DISCLOSED, OR REPRESENTS THAT ITS USE WOULD NOT INFRINGE PRIVATELY OWNED RIGHTS. 
DEMOLITION AND REMOVAL OF PLUTONIUM-CONTAMINATED

FACILITIES AT HANFORD

M. N. RAILE

PROJECT ENGINEERING DEPARTMENT

RESEARCH AND ENGINEERING DIVISION

ATLANTIC RICHFIELD HANFORD COMPANY

RICHLAND, WASHINGTON 99352

OPERATED FOR THE UNITED STATES ENERGY RESEARCH AND

DEVELOPMENT ADMINISTRATION BY ATLANTIC RICHFIELD

HANFORD COMPANY UNDER CONTRACT AT(45-1)-2130

TOTAL PAGES

NUMBER OF TABLES 3

NUMBER OF FIGURES 22

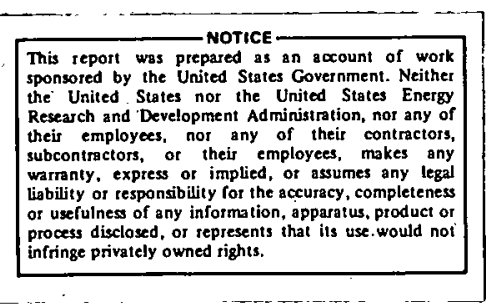




\title{
DEMOLITION AND REMOVAL OF PLUTONIUM-CONTAMINATED
}

FACILITIES AT HANFORD

\author{
INTRODUCTION \\ HISTORY \\ SUPPORT FACILITIES \\ DEMOLITION.AND REMOVAL \\ SITE RESTORATION AND RELEASE \\ OTHER RELATED PROGRAMS
}




\section{ASTRACT}

This paper describes the successful demolition and cleanup of a plutonium-contaminated facility at the U.S. Energy Research and Development Administration Hanford Plant in Washington State. Several new materials, along with special techniques and equipment, were utilized for the containment and control of plutonium contamination during the course of the demolition work. The use of light-capacity fiberglassed plywood boxes for long-term (20-year, minimum) storage of the contaminated materials in underground transurantc waste trenches has led to the development, design and use of larger capacity modular fiberglassed plywood boxes that are replacing standard carbon steel boxes at less than one-third the cost, and without the potential for early failure from normal soil or atmospheric corrosion. 
DEMOLITION AND REMOVAL OF PLUTONIUM-CONTAMINATED

FACILITIES AT HANFORD

INTRODUCTION

This report summarizes methods and techniques employed at Hanford the past year for cleanup, packaging, and removal of plutonium-contaminated facilities for 20-year retrievable storage. Details of the exact scope of the work involved, methods, and techniques are covered for possible. application on other U. S. Energy Research and Development Administration programs of environmental concern. The objectives of the demolition and removal program were to restore the area to its natural state so that it would not pose an environmental hazard to people or animals, and to allow. alternative uses of the land area, if so desired. The following criteria were used as the basis for achieving these objectives:

- Conditional public access or use of the cleaned area shall not result in risk to human health and welfare from radioactive materials.

- There shall be no radiation exposure above and beyond the natural background exposure.

- Potential harmful effeets to the biota from radioactivity shall be eliminated.

- Airborne contamination, and subsequent migration of radioactive material in the event of a range fire or other nature phenomena, shall be eliminated. 
- The removed radioactive materials shall be capable of being stored for 20-year (minimum) retrievability, and controlled at a minimum of cost and surveillance.

\section{HISTORY}

The principal subject of the demolition and removal program is commonly identified as the P-11 facility, which served as a laboratory for plutonium criticality studies at Hanford prior to 1952 (figure 1). The 120 Building, which was a single story metal building about 32 feet by 42 feet in plan contained the critical assembly room, a small chemistry laboratory, storage and tank room, and a change room. Drain. lines from the building and process equipment were routed to an underground waste crib for retention of any disposed radioactive nuclides in the soil (figure 2). A critical excursion in 1951 resulted in extensive plutonium contamination to the interior of the 120 Building. During the final stages of decontamination work to reactivate the facility, a fire broke out in the southwest part of the building apparently from spontaneous ignition of decontamination materials. The fire gutted the storage room and chemistry laboratory, burned through the ceiling, melted the aluminum filter ducts, and set fire to the exhaust filters, resulting in extensive contamination throughout the building (figure 3 ). The contamination was fixed using sealants and concrete grout with eventual abandonment of building and site in consideration of the high risk and cost to decontaminate and restore the 
facility for continued criticality studies. Contamination levels found prior to the start of demolition work are shown in Table 1.

\section{SUPPORT FACILITIES}

A number of support facilities were required to be procured or fabricated, tested and installed prior to demolition.

The principal auxiliaries were the (1) airlock; (2) ventilationfiltration system, (3) radiation monitoring system, and (4) utilities which included water, power and telephone services: In conjunction with these items a 60-foot mobile trailer for office and lunchroom, and a 12-foot trailer for special clothing and materials used for working with radioactive contamination were located at the site.

An airlock was installed which was critical to effective contamination control and included (1) a room where filled waste containers and work personnel could be surveyed, (2) a clothing change room, (3) a radiation equipment monitoring room, and (4) a special material storage room (figures 4 and 5). A ventilation-filtration exhaust unit was added which included a nine-bank HEPA filter housing with corresponding prefilters, and a seven and one-haif horsepower blower. The rated capacity was 7,500 cubic feet per minute, providing about three air changes per minute. A constant alpha air monitor was installed downstream of the filter bank and provided continuous monitoring of the stack exhaust with alarm 
annunciation and recording inside the radiation monitoring room (figure 6). A Radiation monitoring system using instruments of the isokinetic type $\left(\right.$ RADECO ${ }^{R}$ - Radiation Detecting Equipment Company) was installed for detecting airborne particulates in the 120 Buildirg, airlock, change room, and the previously mentioned exhaust stack. The 120 Building with airlock and ventilation exhauster installed is shown in figure 7 .

\section{DEMOLITION AND REMOVAL}

Preliminary work prior to actual demolition of the 120 Building involved clearing the fenced area around the 120 Building of rock and sand overburden spread around as a precautionary measure when the site was abandoned. Low level contamination was uncovered, but did not extend beyond the foundation, indicating that the water used in fire fighting did not permeate over a large area. The concrete was covered with wet rags to contain dust and chipping fragments. The removed concrete was surveyed and loaded into 55-gallon steel drums lined with 12 mil polyvinyl plastic. Each container was sealed with a standard drum lid clamp and weighed, using a dynamometer attached to the lifting crane (figure 8). This would be the standard procedure for handling all material removed and loaded out. The various types of containers used included (1) fiberglass reinforced polyester (FRP) 
plywood boxes, (2) steel boxes, (3) standard and coated 55-gallon drums, and (4) standard plywood boxes constructed at the site as needed. The FRP boxes, steel boxes, and coated 55-galion drums were used for transuranic waste destined for 20-year retrievable storage (figures 9 and 10). The total volume and weight of the various type wastes removed are shown in Table 2. The basis for determining transuranic disposal was U. S. Energy Research and Development Administration Manual Chapter 0511, with a more conservative limit established to simplify and minimize radiation monitoring surveys. Any material or equipment surveyed showing contamination exceeding ten nanocuries per gram $(22,500 \mathrm{~d} / \mathrm{m}$ maximum, anywhere) was automatically classified as transuranic waste, regardless of weight or distribution, and sealed in approved containers for 20-year retrievable storage in underground trenches. Major equipment used in the demolition and cleanup work is shown in Table 3.

All major leaks in the 120 Building skin were sealed to insure a good differential pressure inside the building. The ventilation filter assembly was checked for leakage by the dioctyl phithalate (DOP) method and tested satisfactorily. The system was sized to provide about three air changes per minute, in view of the anticipated heat buildup inside the building during the summer months. It was also necessary to fix the 
smearable contamination inside the 120 Building before actual demolition could be started. This was accomplished by spray painting the interior surfaces with a water soluble latex paint. An airless spray gun was used, and the exhaust system turned off, to minimize the amount of airborne contamination.

Neutron and gamma counting equipment was used to determine the amount of plutonium in the cells (figure 11). The readings were somewhat inconclusive due to density of concrete, depth of plutonium, and other factors. However, it was determined that the total amount of plutonium was comparable to the amount estimated from accountability figures within measurement error.

The heavily contaminated cells and floor were cleaned to remove loose contamination and then covered with Butvar $B^{R}$ (Monsanto Chemical Company) dispersion, a strippable coating (figures 12 and 13). The coating is a plasticized polyvinyl butyral dispersion in water and is effective in fixing contamination which minimized dusting and airborne contamination while contaminated concrete was being chipped.

\section{SITE RESTORATION AND RELEASE}

Despite continuous monitoring of site and work area for alpha contamination during demolition, an extensive survey and soil sampling program was instituted at the conclusion of 
the demolition work. Soil samples were taken to a depth estimated at one-foot into undisturbed soil and encompassing the entire exclusion and crib areas. No plutonium counts were obtained from any of the soil samples using a portable alpha (poppy) survey instrument.

In order to ascertain stability of the soil in the event of high winds, the site area was rilled to a three-inch depth and seeded with a rapidly germinating mixture of cereal rye grass and Siberian wheat grain. The area was resurveyed and released for normal access as defined under restrictions and regulations in effect at Hanford. A standard survey site marker with pertinent documentary information, coordinates, and historical dates has been located at the center of the 120 Building site (figure 14).

\section{OTHER RELATED PROGRAMS}

Related programs are under way, or are being planned at Hanford for the decommissioning and cleanup of other plutoniumcontaminated facilities that are inactive or abandoned, and are of environmental concern. The current active program involves the removal. of obsolete Division of Military Application (DMA) equipment from the 234-5Z Building for packaging and storage in underground trenches for 20-year (minimum) retrievability. The facilities include glove boxes attached to central service conveyors and related auxiliary 
equipment such as hydraulic pumps, filter boxes, control panels and the like (figures 15 and 16). All glove boxes and equipment are surveyed for alpha contamination and radiation levels prior to start of any work. In addition, all glove boxes and equipment are counted for any residual plutonium. using a portable sodium iodide (NaI) gamma detector before removal work can be started (figure 17 ).

Gloves and other combustibles are removed from glove boxes where feasible, and packaged separately in coated steel 55-gallon drums. The glove ports are covered with formed aluminum cover plates and tape sealed. Flanged openings to conveyor are sealed with gasketed light gauge sheet metal. The glove box ventilation exhaust system is maintained at a negative pressure of one-half to one inch of water until the glove box is removed from the conveyor. If the glove box cannot be loaded and sealed into a storage box within 24 hours, a temporary exhaust must be installed (figure 18). Removal of the glove box from the conveyor is accomplished by "horsetailing" which involveśs using a long plastic sleeve between connecting flanges, breaking the glove box away from the flange, followed by wrapping excess plastic in a tight roll and cutting in the center. The cut ends are seaied with cloth-backed tape and sandwiched behind the sheet metal flange cover plates. Where fine plutonium oxide dust may be 
present, the inside of the glove box near the connecting flange is sealed with Butvar $B R^{B}$ dispersion to fix the contamination.

The glove boxes are loaded into Fiberglass Reinforced Polyester (FRP) plywood boxes which were designed and developed at Hanford. The FRP boxes are modular in design and double-wall construction for earth load (figure 19). The same size box components are interchangeable and boxes may be shipped unassembled, thus reducing freight cost which could be significant. Three standard sizes are utilized at Hanford which are 12, 16, and 20 feet long, respectively, with all being 8-feet wide by 8-feet high. A water and chemical resistant adhesive (Scotch Grip $\mathbb{B}_{5230}$ - Minnesota Mining and Manufacturing Company) is used to seal both inside and outside joints on assembly. The external joints are then covered with fiberglass cloth and resin, as is the lid to box joint after material is loaded into the box. The boxes are weighed. using a dynamometer attached to a crane hook, loaded onto a flatbed truck, using the railroad tie skids as lift points, and transported to the designated underground trench (figures 20,21, and 22). The load capacity of the FRP box is calculated to be approximately 50,000 pounds. A four-foot (minimum) earth cover is placed over the boxes in the trench. 
The average cost for the FRP box assembled and delivered is about $\$ 3,000$, with a volume capacity of 750 cubic feet. A standard Hanford steel box Type I, with a volume capacity of 250 cubic feet, costs about $\$ 2,200$, thus making the FRP box much more economical. In addition, corrosion of fiberglass in soil is considered nil. It is planned to uncover one of the boxes in three to five years to determine the effect of Hanford soil on fiberglass. 


\section{P-II SURVEY}

Direct $d / m \quad$ Smears $d / m$

Cell \#1

Miscellaneous spots on steel structure

Panel board base

Stepladder

Rungs of Fixed ladder

Safe on floor

$2^{\prime \prime} \times 4^{\prime \prime} s$ bolted to wall (upper)

2" $\times 4$ "s bolted to wall (lower)

Cell $\stackrel{2}{\div 2}$

Horizuntal Surfaces

to 20,000

5,000

10,000

5,000

500

5,000

10,000

5,000

1,000

2,000

2,000

$<500$

1,000

$<500$

2,000

1,000

Lab

Hall under mix room window

Horizontal surfaces (general)

50,000
to $\quad 5,000$

$\begin{array}{ll} & 5,000 \\ \text { to } \quad 1,000\end{array}$

Mix Room

Small duct over concrete fill

Pipe braces on wall

Vialls above concrete fill

$$
\begin{array}{r}
100,000 \\
20,000 \\
1,000,000
\end{array}
$$

20,000

5,000 300,000 .

Chànge Room

Top of shower

Sinks, water tank and miscellaneous surfaces

5,000

1,000

2,000

1,000

East Corridor

Miscellaneous material in plywood box to

5,000

No smears.

hork benches, Power tools, Floors and adjacent walis

to

2,000

to

1,000

Attic

Vent duct over mix room

Miscellaneous horizontal surfaces

to

20,000

1,000

All readings were corrected using factor, $x 10$

Personnel Survey at completion of work

$\begin{array}{lrr}\text { Coveralls } & <500 \mathrm{~d} / \mathrm{m} \\ \text { Shoe covers } & <500 \mathrm{~d} / \mathrm{m} \\ \text { Gloves } & \text { to } \quad 500 \mathrm{~d} / \mathrm{m}\end{array}$

Spot check with G.M. Inst. (all rooms) $<200 \mathrm{c} / \mathrm{m}$ 


\section{P-II FACILITY}

WASTE DISPOSAL SUWWARY

Type of Container

55 Gallon drum, mixed fission products

55 Galion drum, transuranic

Fibre Glass reinforced plywood box

Plywood box

Steel box

Truck load

Transuranic burial

Mixed fission products burial

No.

268

17

5

5,200

73

2

6

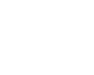




\section{MAJOR EQUIPMENT USAGE}

\section{ITEM}

Pettibone
$12-1 / 2$ ton Hydrocrane
Case
750 Crane-Backhoe-Loader
Lorraine
$1 / 2$ Yard Backhoe
American
$45-$ ton Crane
Huff
$2-1 / 2$ yard Front: End Loader
International
$40^{\prime}$ Semi-truck
2 ton Flatbed
D- 15 Bulldozer
Ingersoll-Rand
A11 Pavement Breaker
Thor
Chipping Gun
B -Brute
Air Compressor
210 cfm and 250 cfm

\section{SERVICE}

Installation of Ventilation-

filtration unit and airlock, also handling of waste containers

Excavation of exterior trenches

Crib excavation

Removal of 120 Building roof

Removal of gravel overburden around 120 Building

Transport of burial containers

Grading and filling of site

Concrete pads and floor demolition

Stripping of concrete floor and cell surfaces

Air supply to air operated equipment

TABLE 3 


\section{LIST OF FIGURES}

FIGURE

1

2

3

4

5

6.

7

8

9

10

11.

12

13

14

15

16

17

18

19

20

21

22
DESCRIPTION

P-11 Site Prior to Demolition

P-11 Waste Crib Uncovered

Burned Out Area of 120 Building

Radiation Monitoring Room

SWP Clothing and Change Room

120 Building Filter - Exhauster Unit

120 Building With Airlock and Filter

Exhauster Installed

Dynamometer Attached to Crane Hook

Hanford Type I and II Steel Storage Box

Light-Duty FRP Plywood Storage Box

Neutron Counting of 120 Building Cell

Survey and Coating of Floor Before Chipping

Contaminated Cell Floor Sealed with

Strippable Coating

Standard Survey Identification Marker -

P-11 Site and Historical Data

Typical Glove Box Attached to Main Conveyor Prior to Removal

Auxiliary Equipment Prior to Removal

Gamma Counting of Glove Box for Residual Plutonium

Temporary Exhaust on Glove Box Removed from Main Conveyor

Modular FRP Box Under Fabrication.

Loading Modular FRP Box on Truck

Equipment Used for Loading Filled FRP

Box on Truck

Filled FRP Box Stored in Trench 
ADVANCED IMAGING SYSTEMS

ANY DOCUMENT, ANYWHERE, ANYTIME - (7O4) 525 -4392

The Following Images) are...

(Check one of the following)

Photocopy

Poor Quality Original

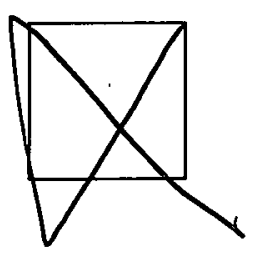

Other

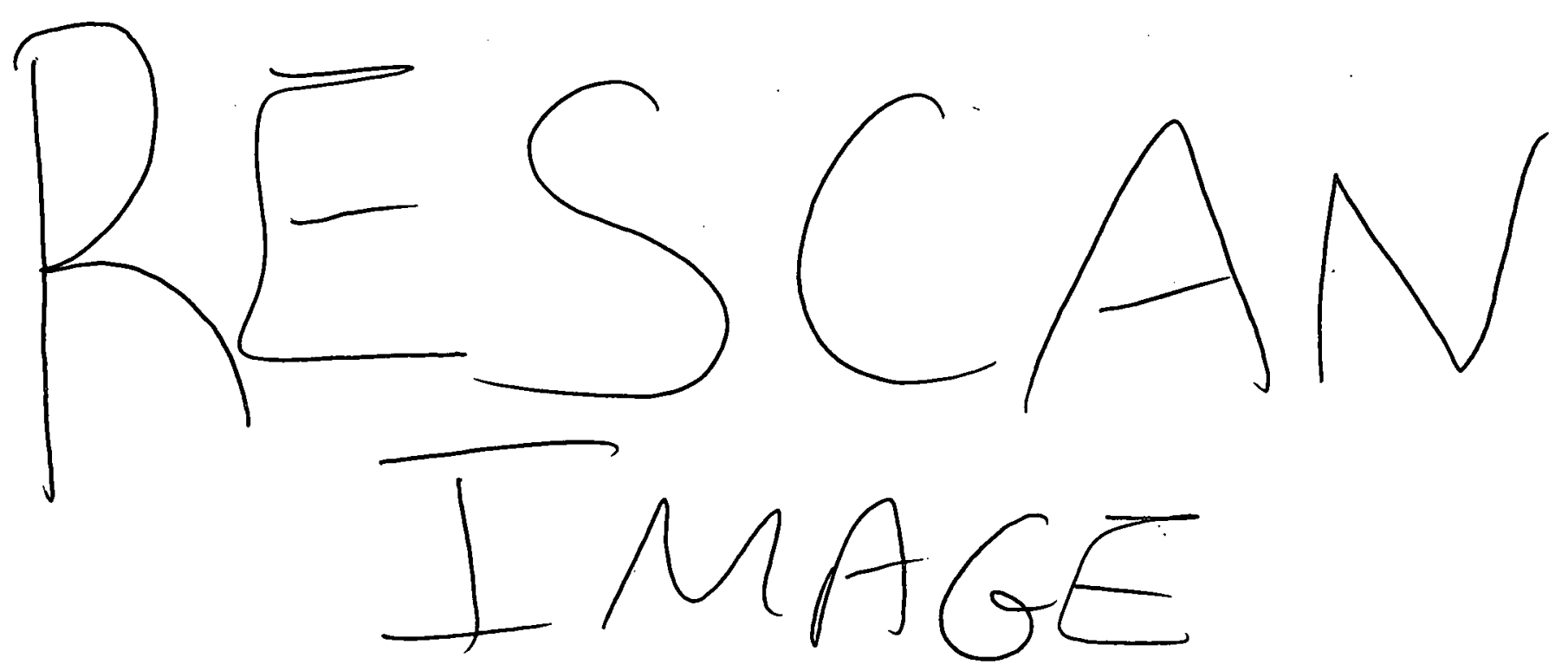




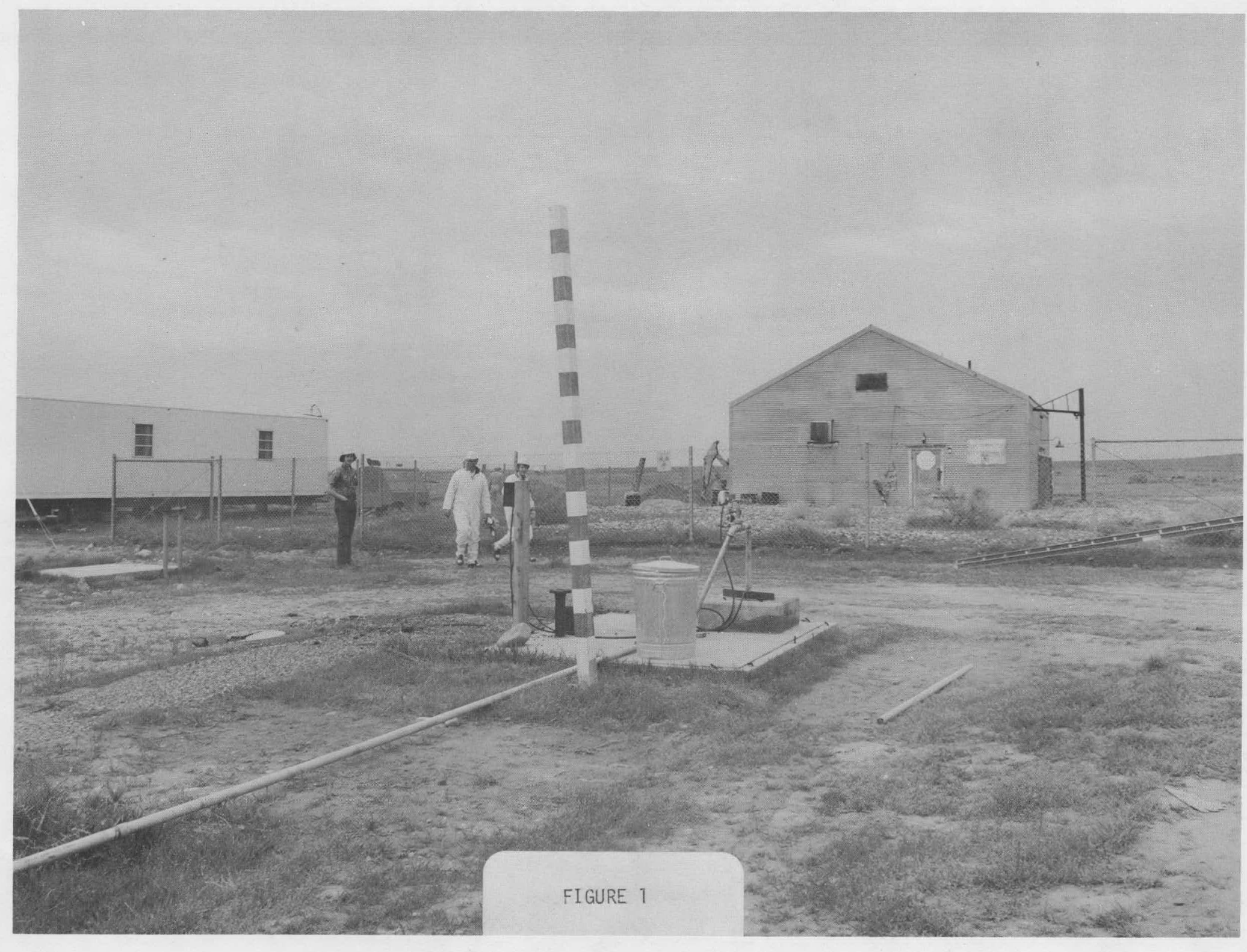




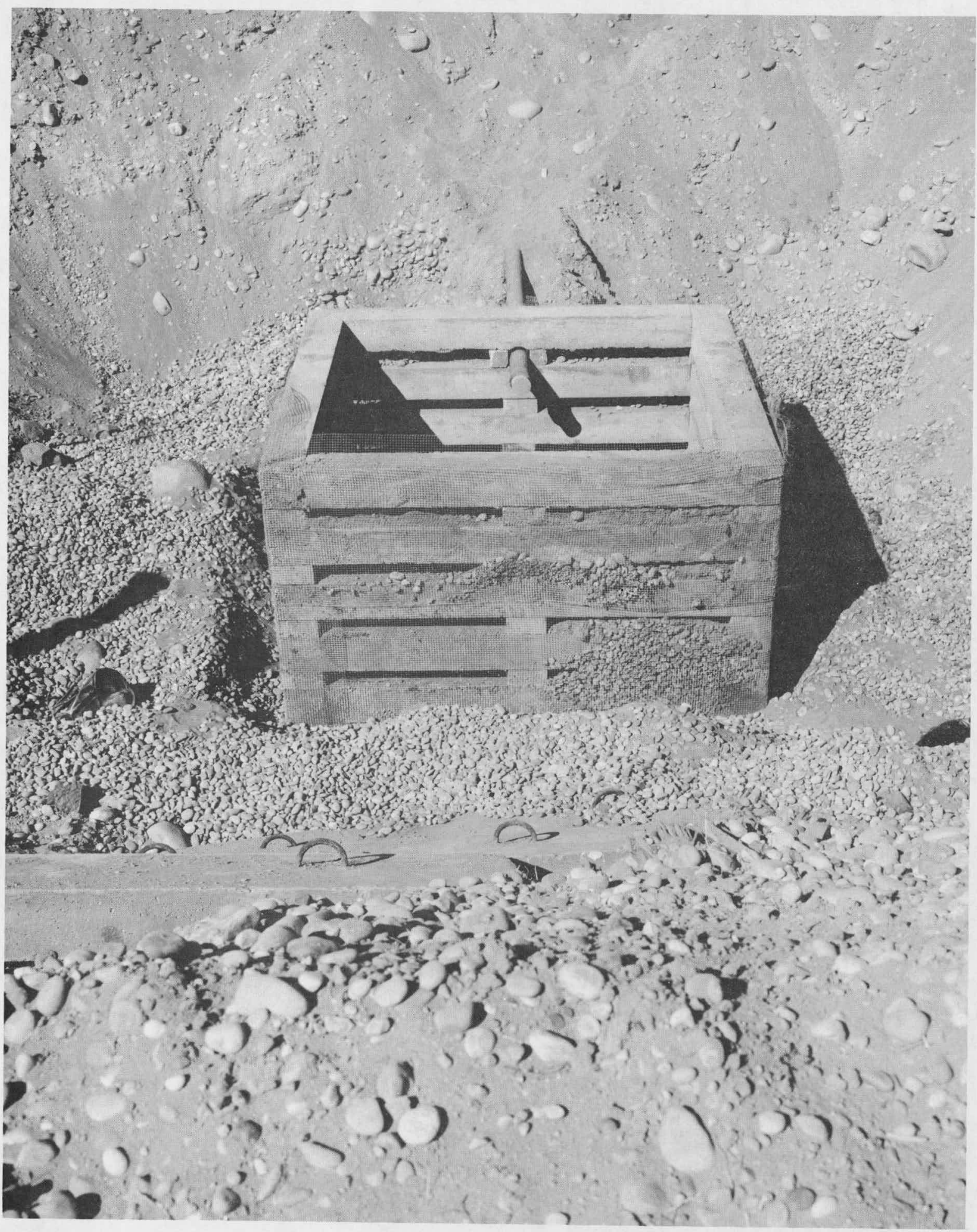




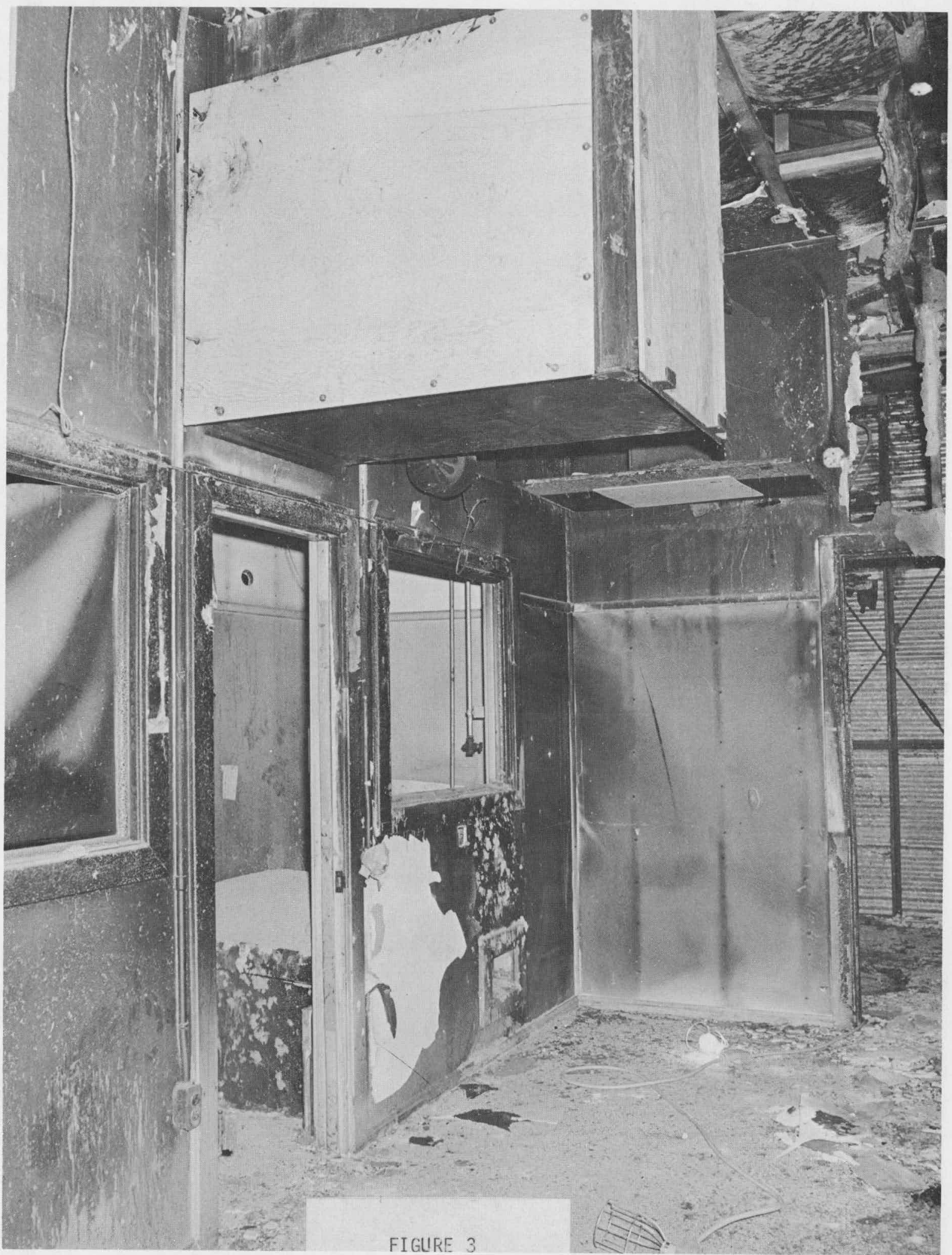




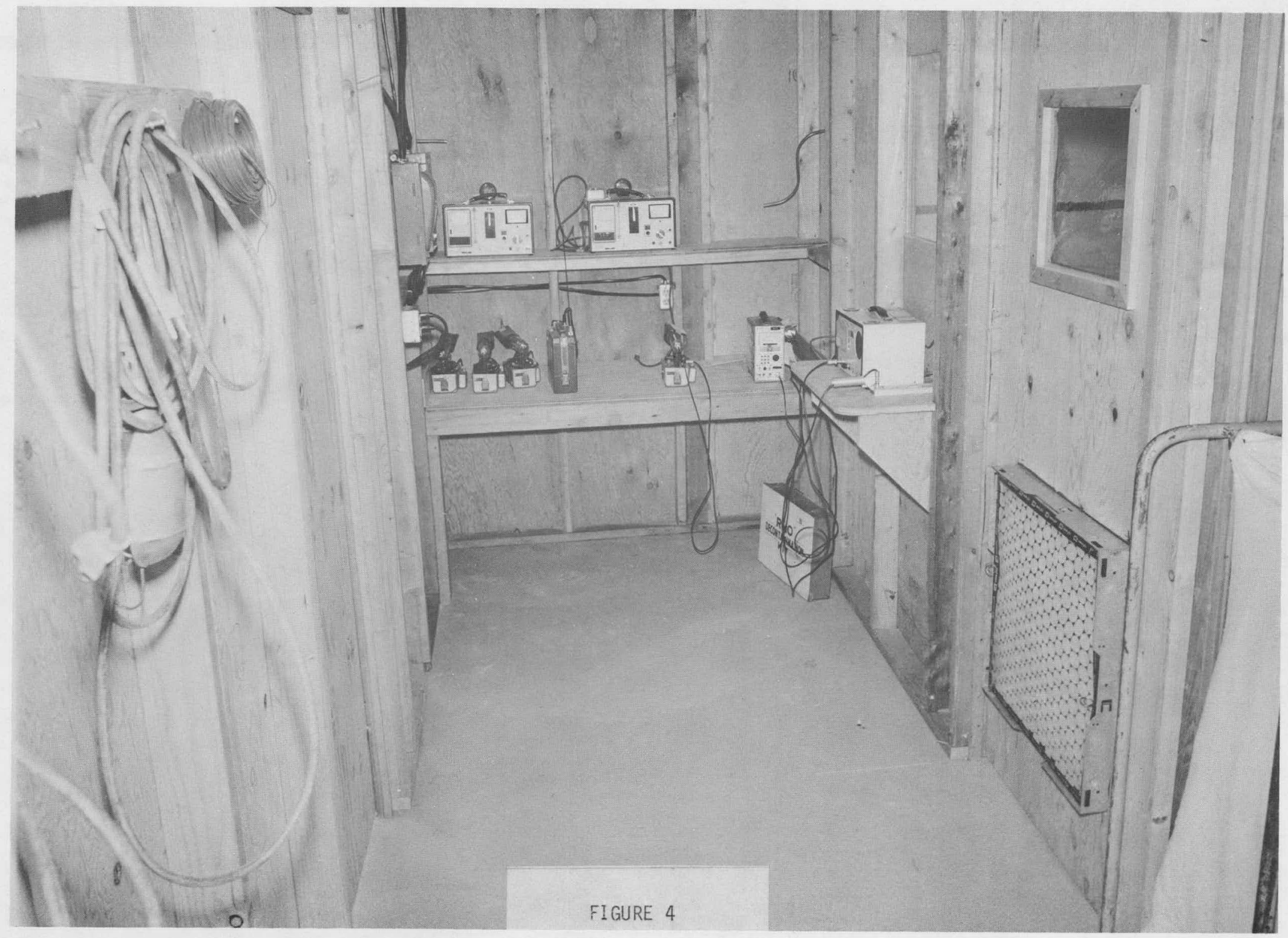




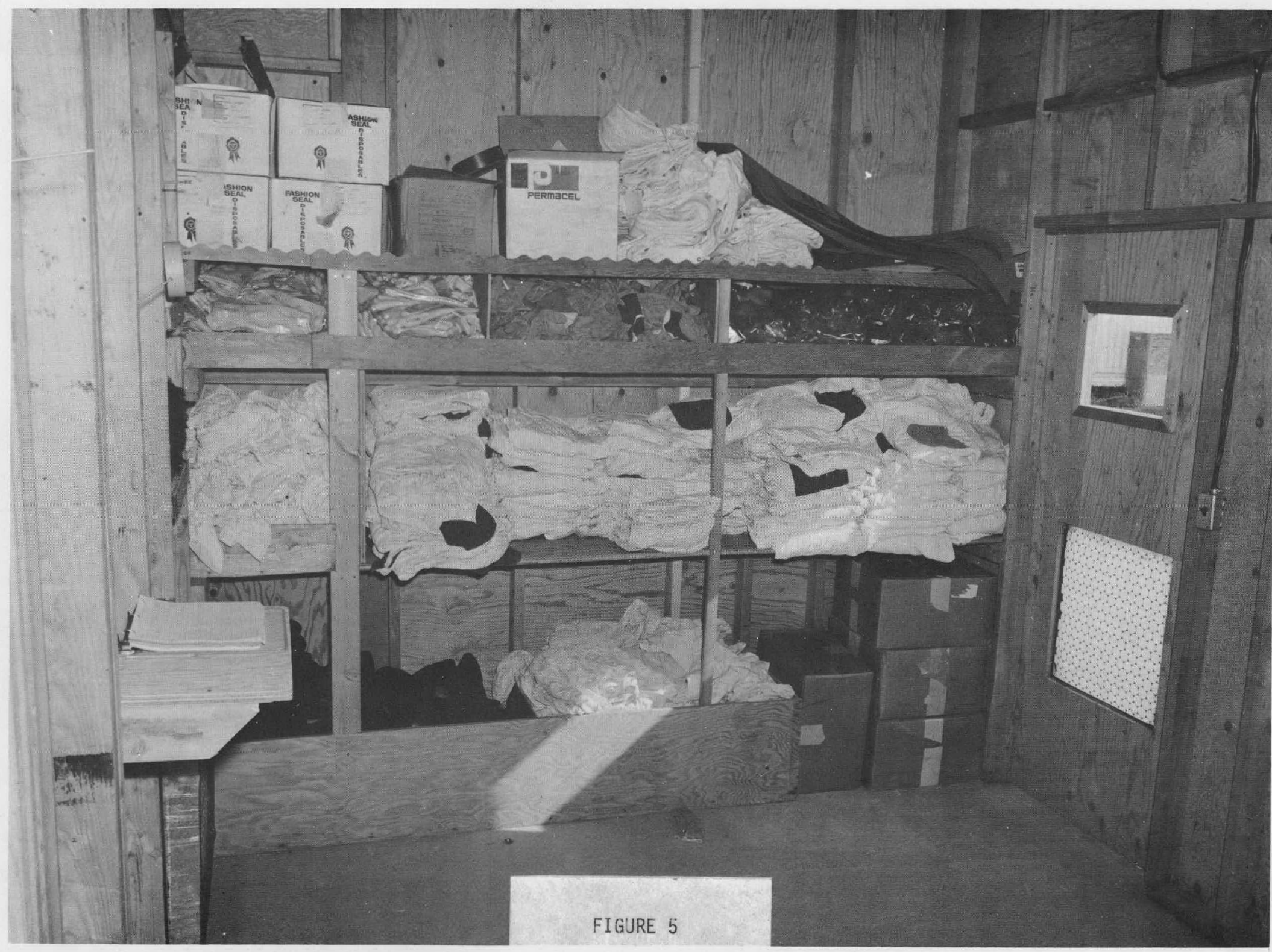




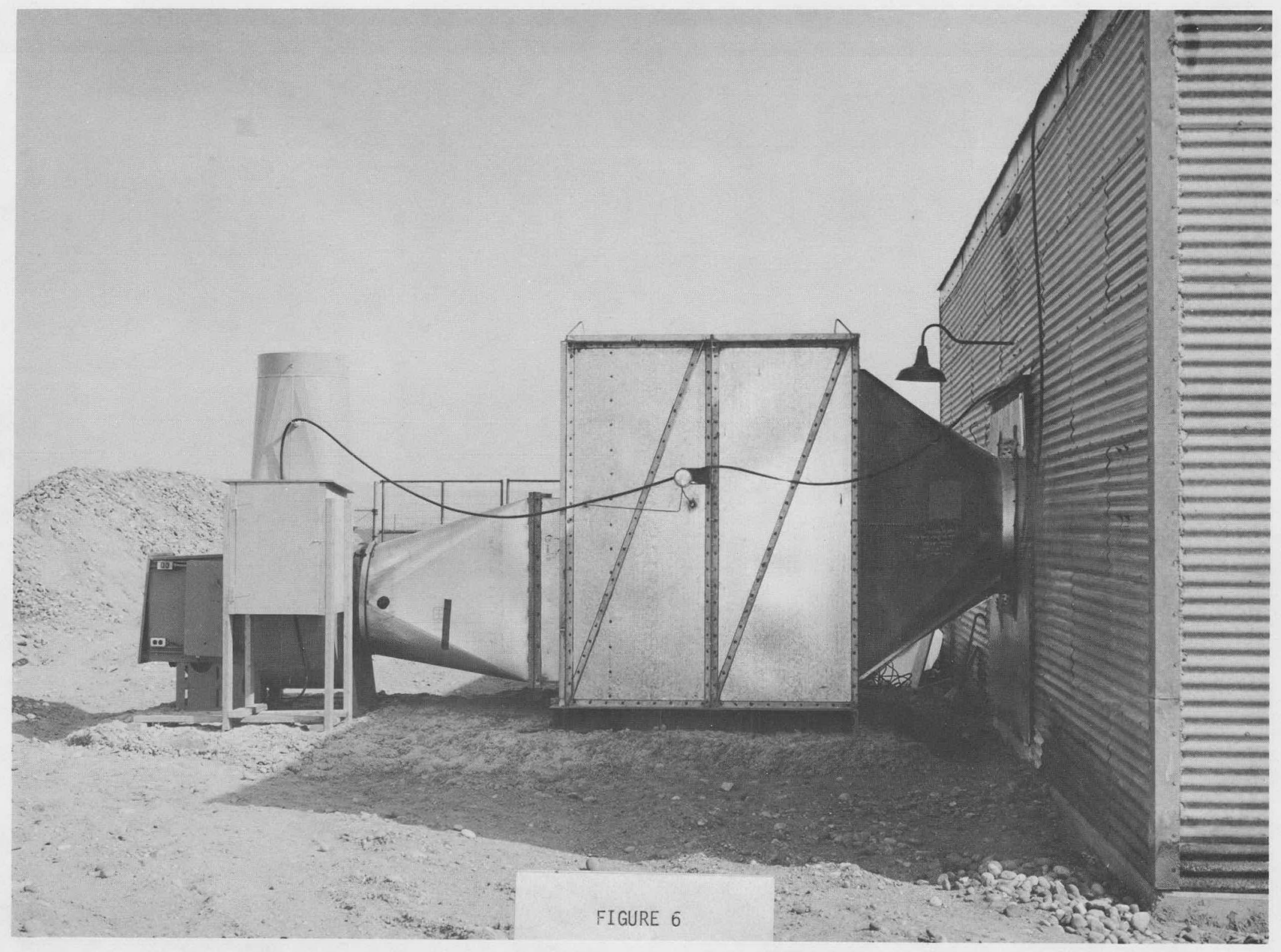




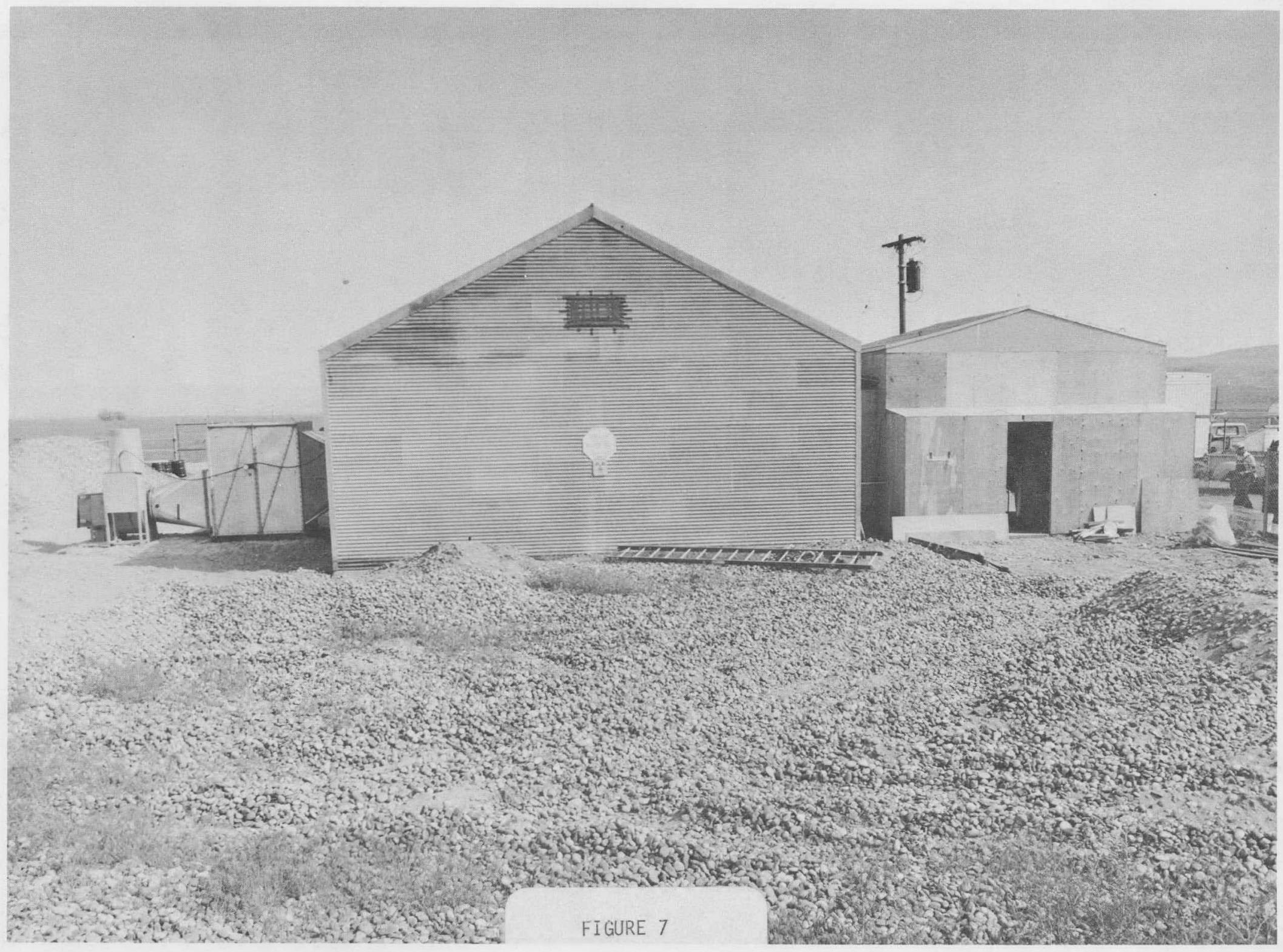




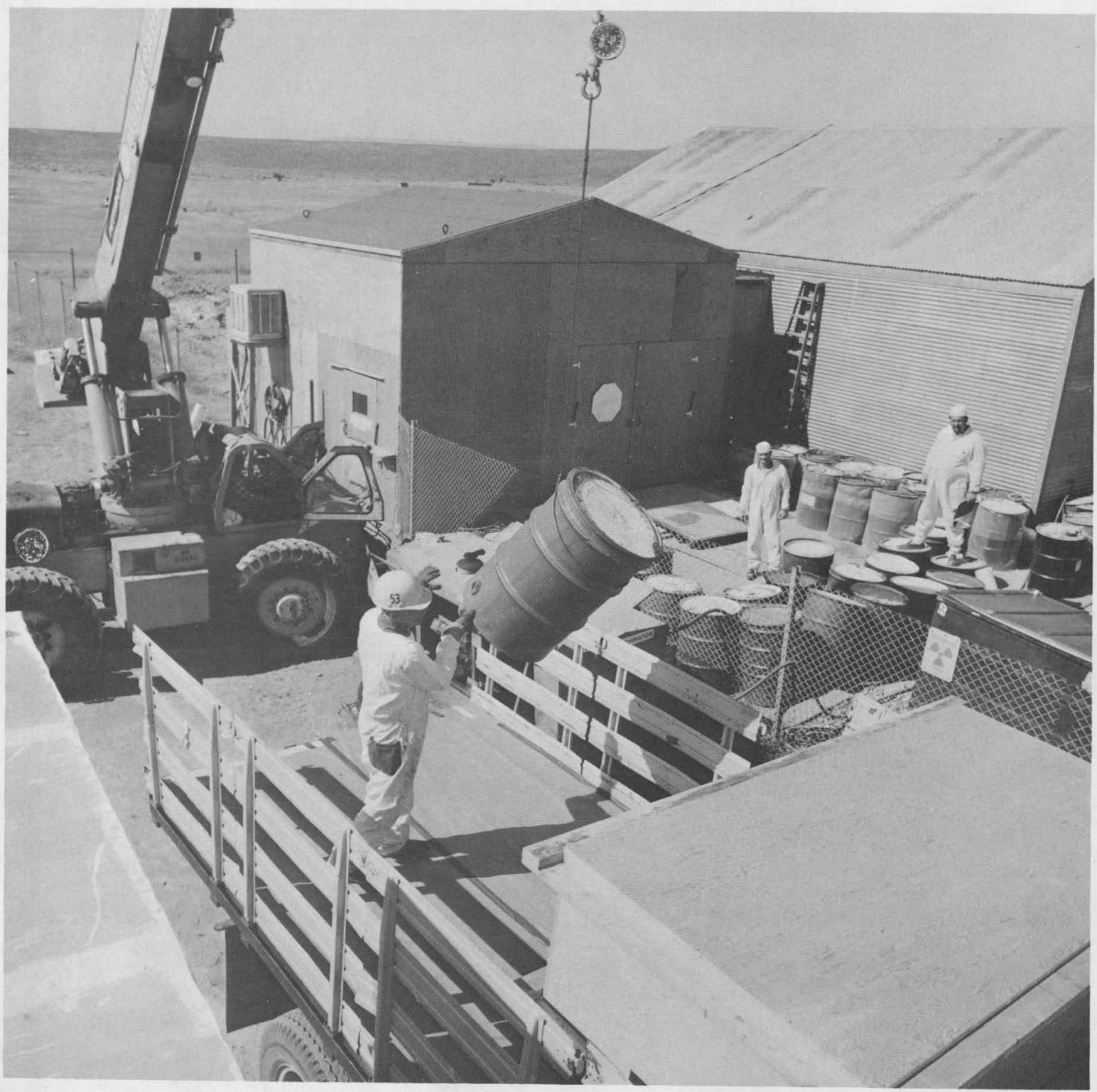

FIGURE 8 


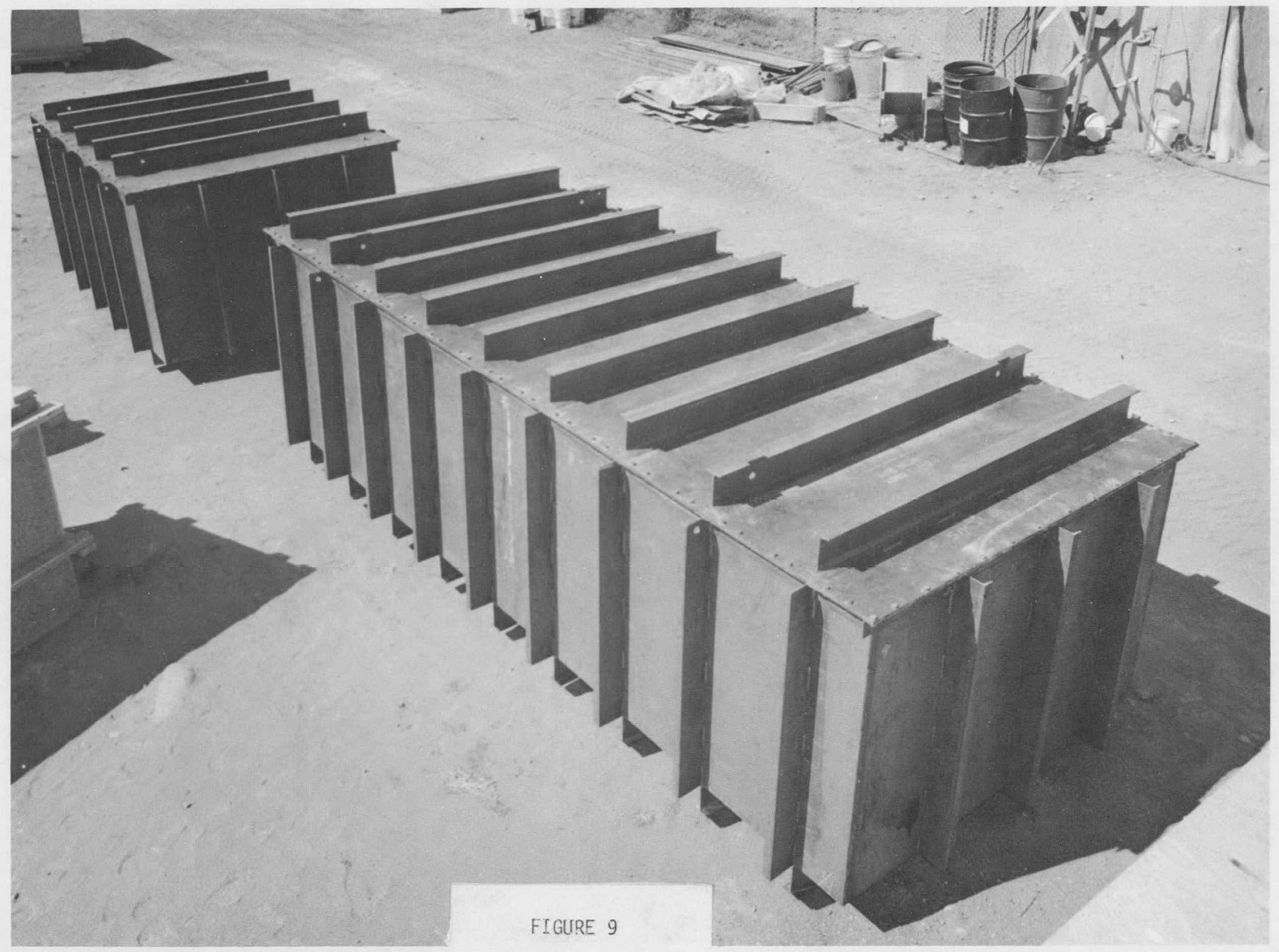




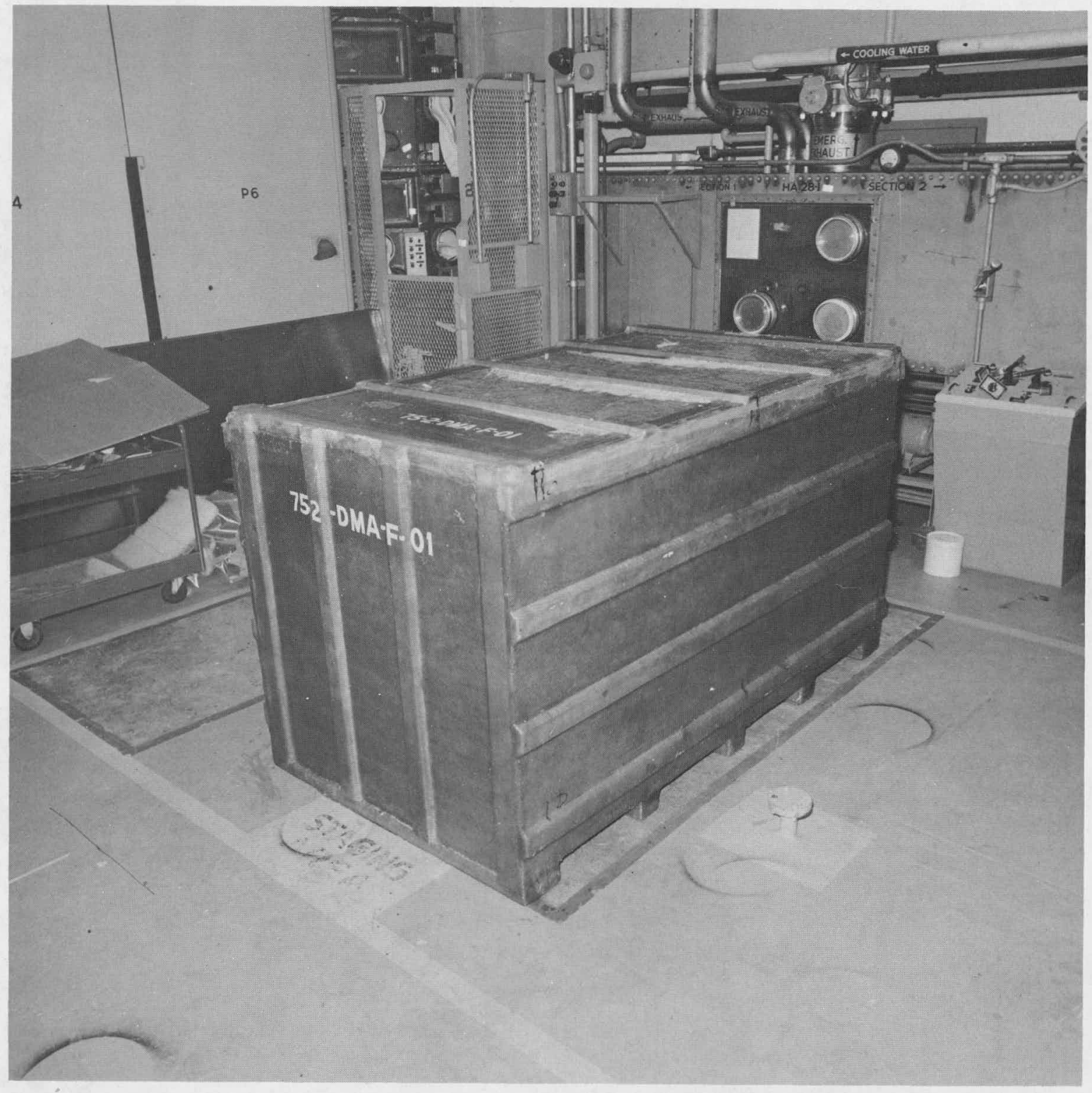

FIGURE 10 


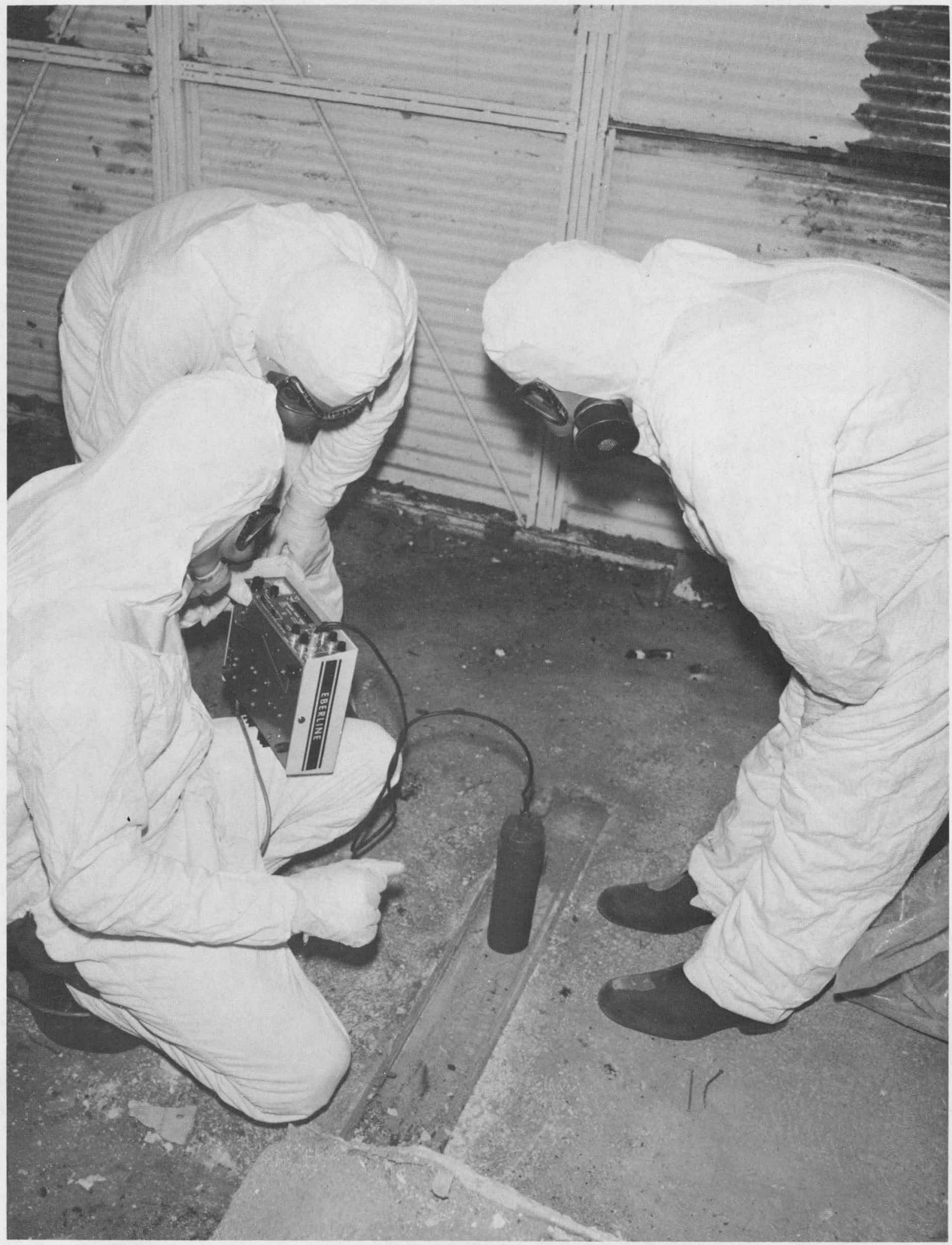




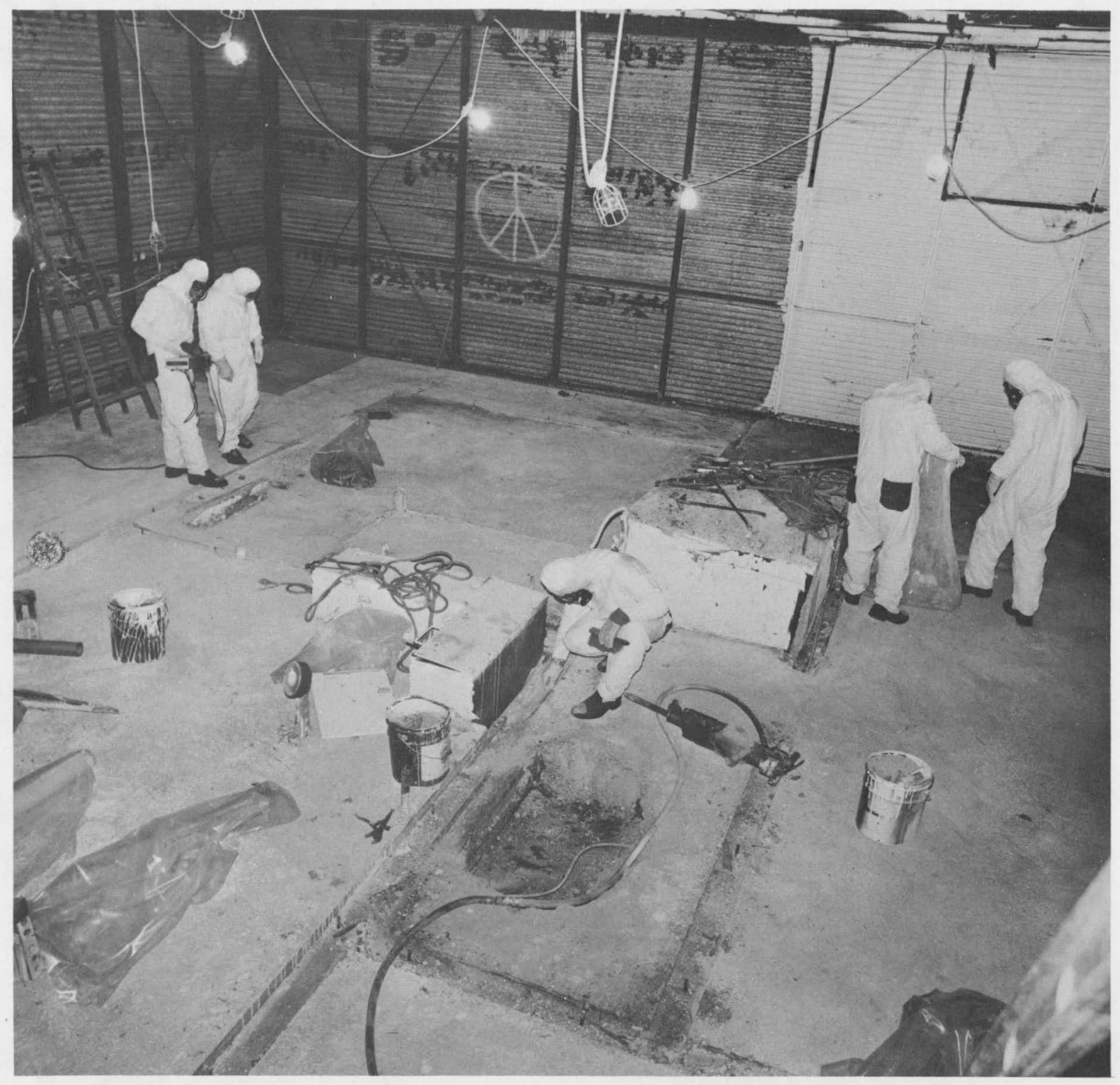

FIGURE 12 


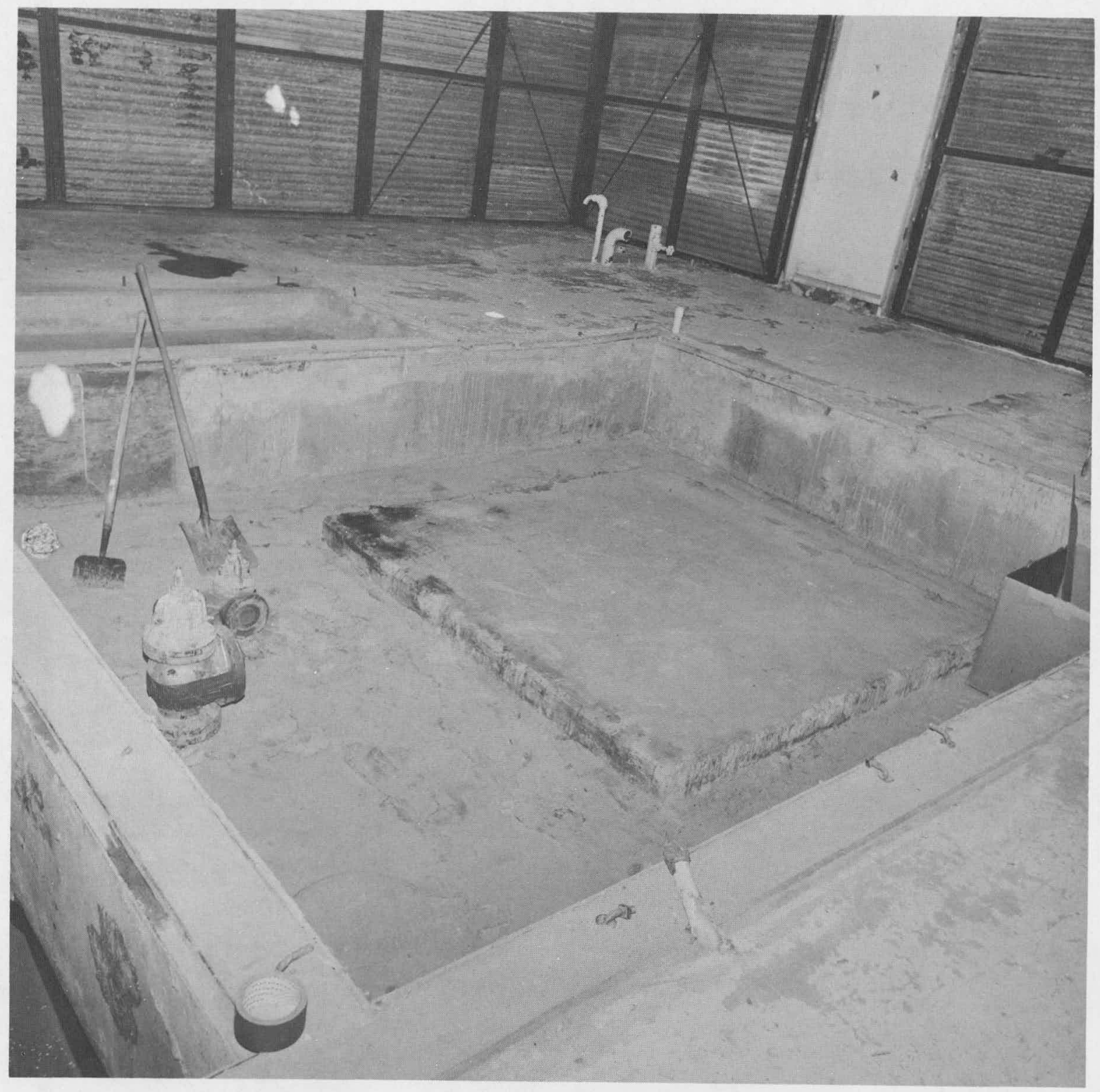

FIGURE 13 


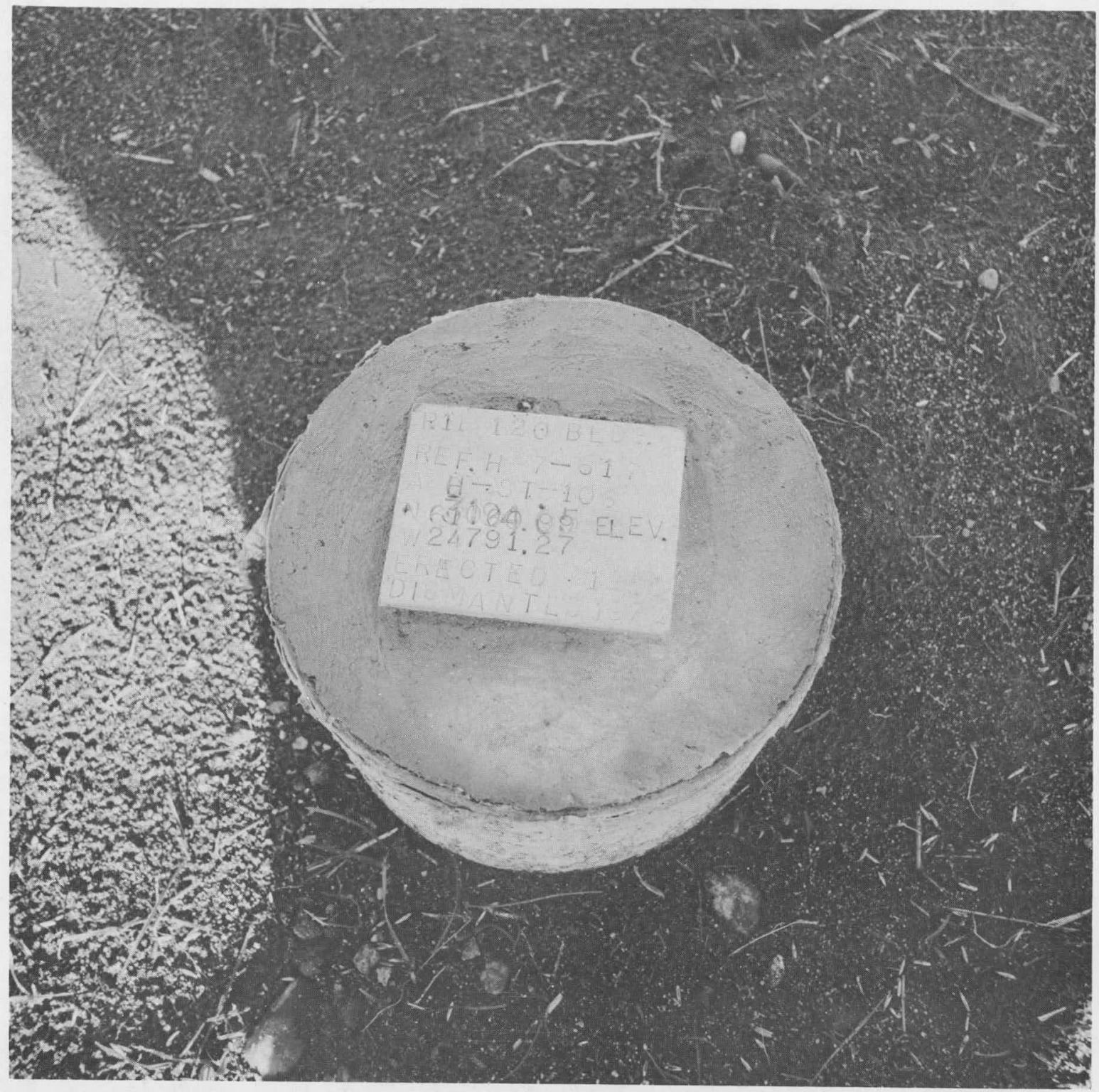

FIGURE 14 


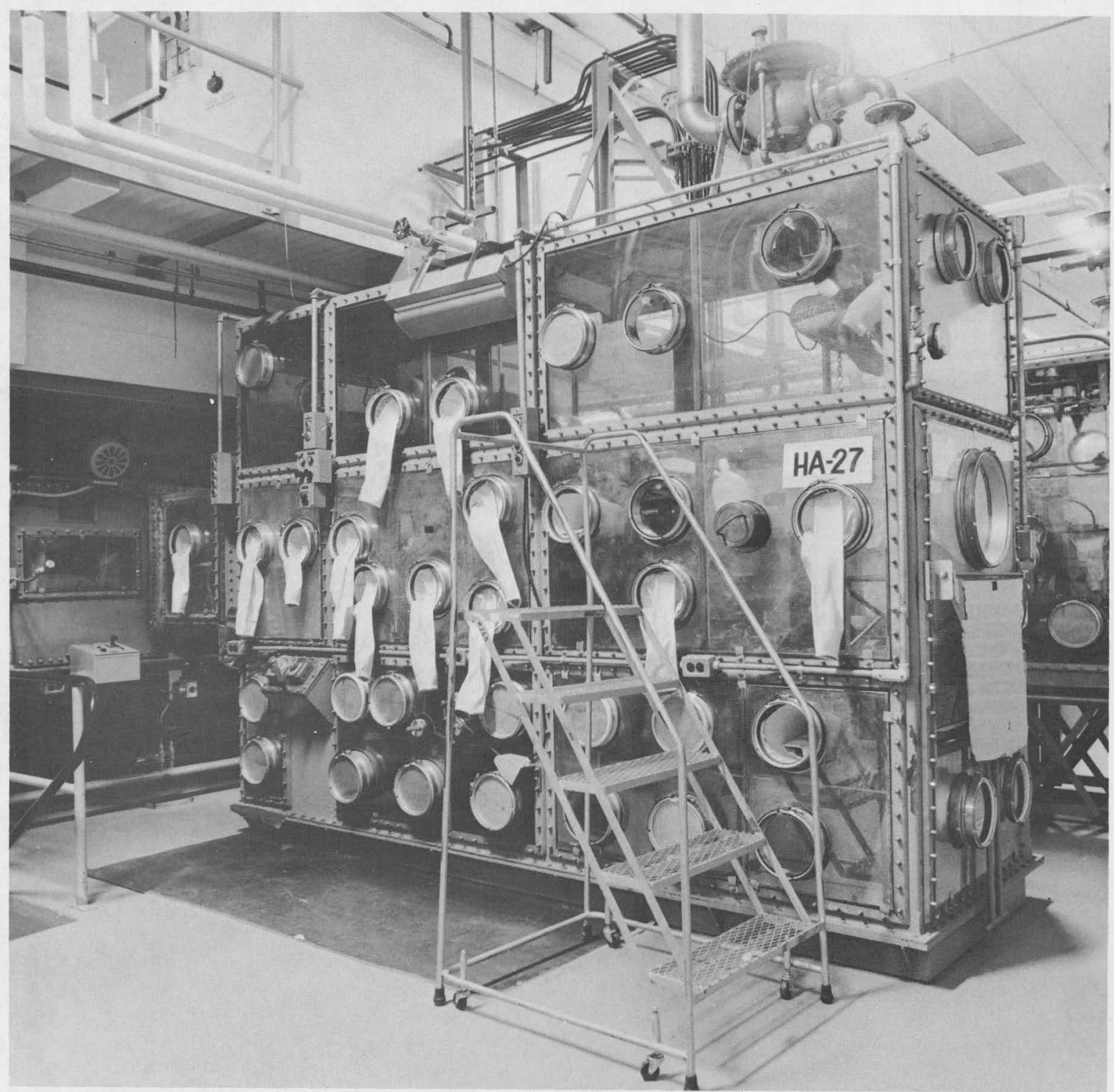

FIGURE 15 


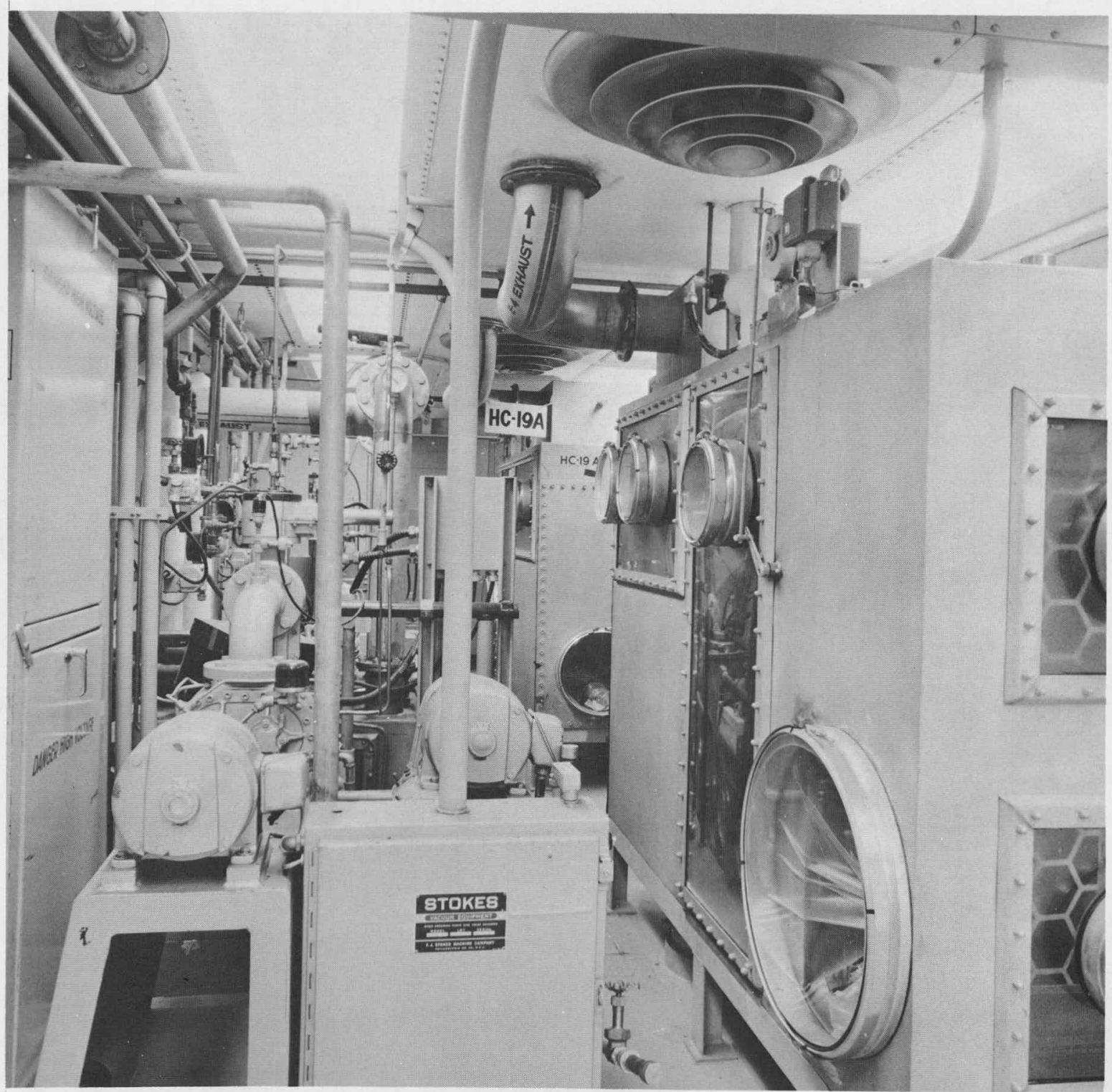

FIGURE 16 


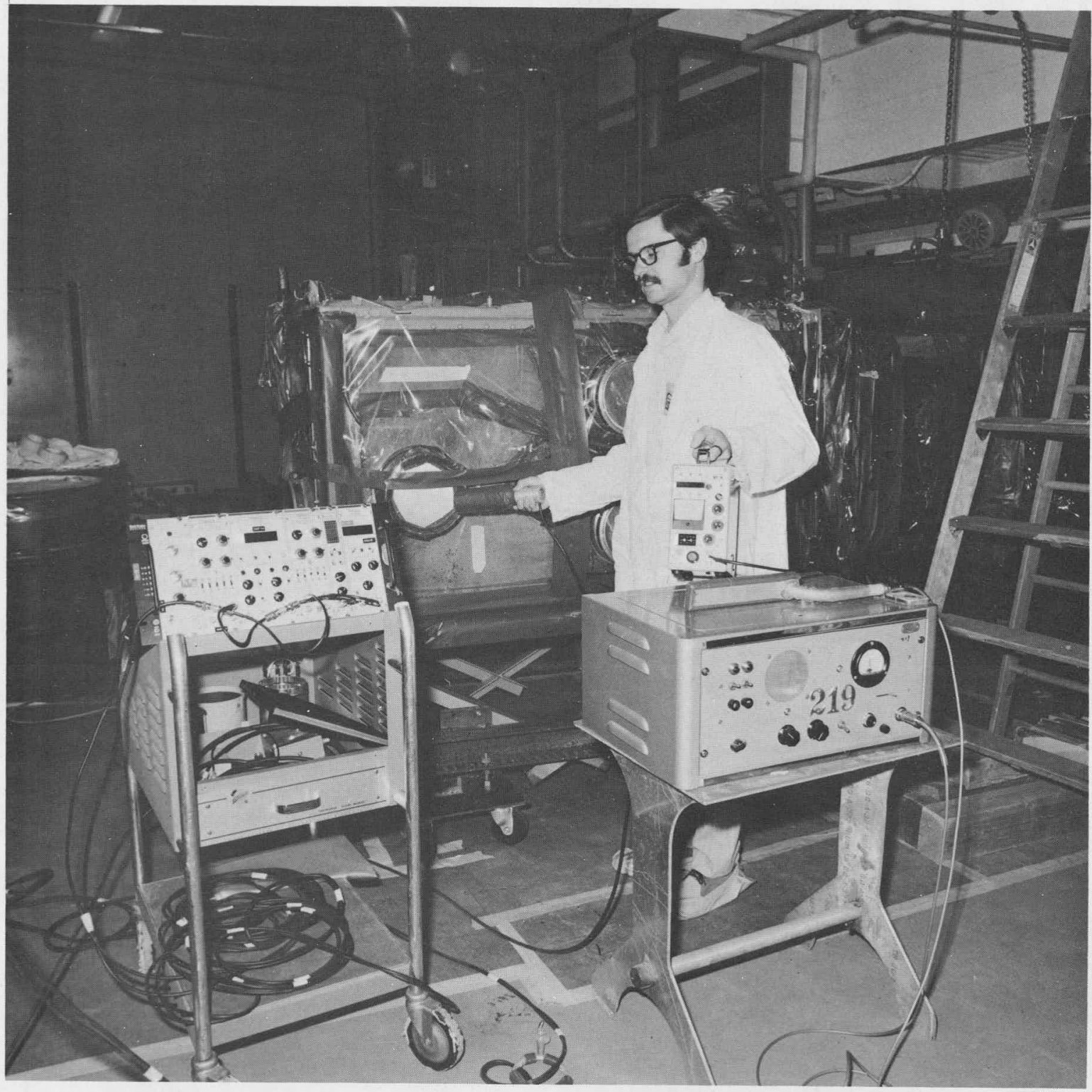

FIGURE 17 


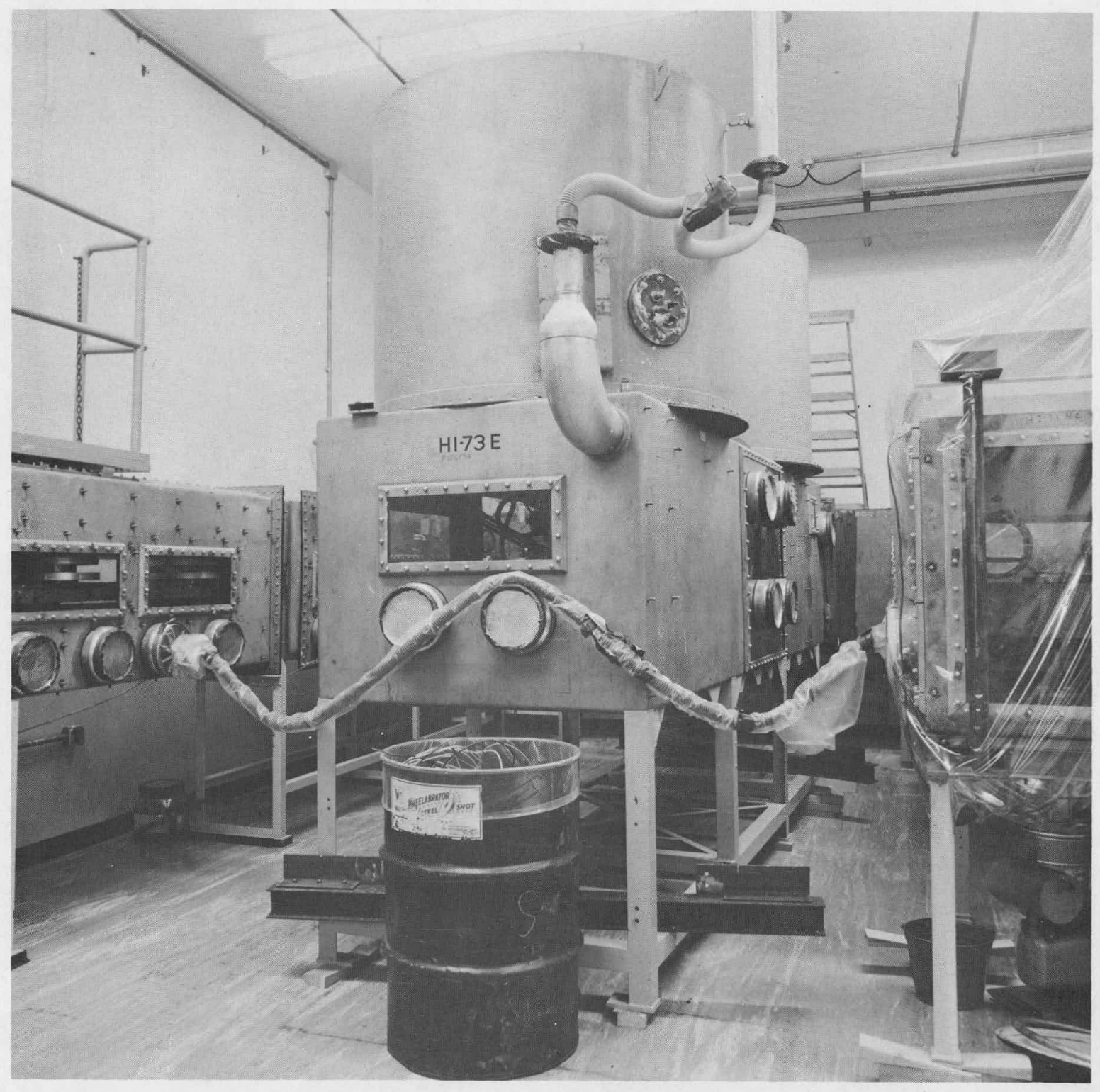

FIGÚRE 18 


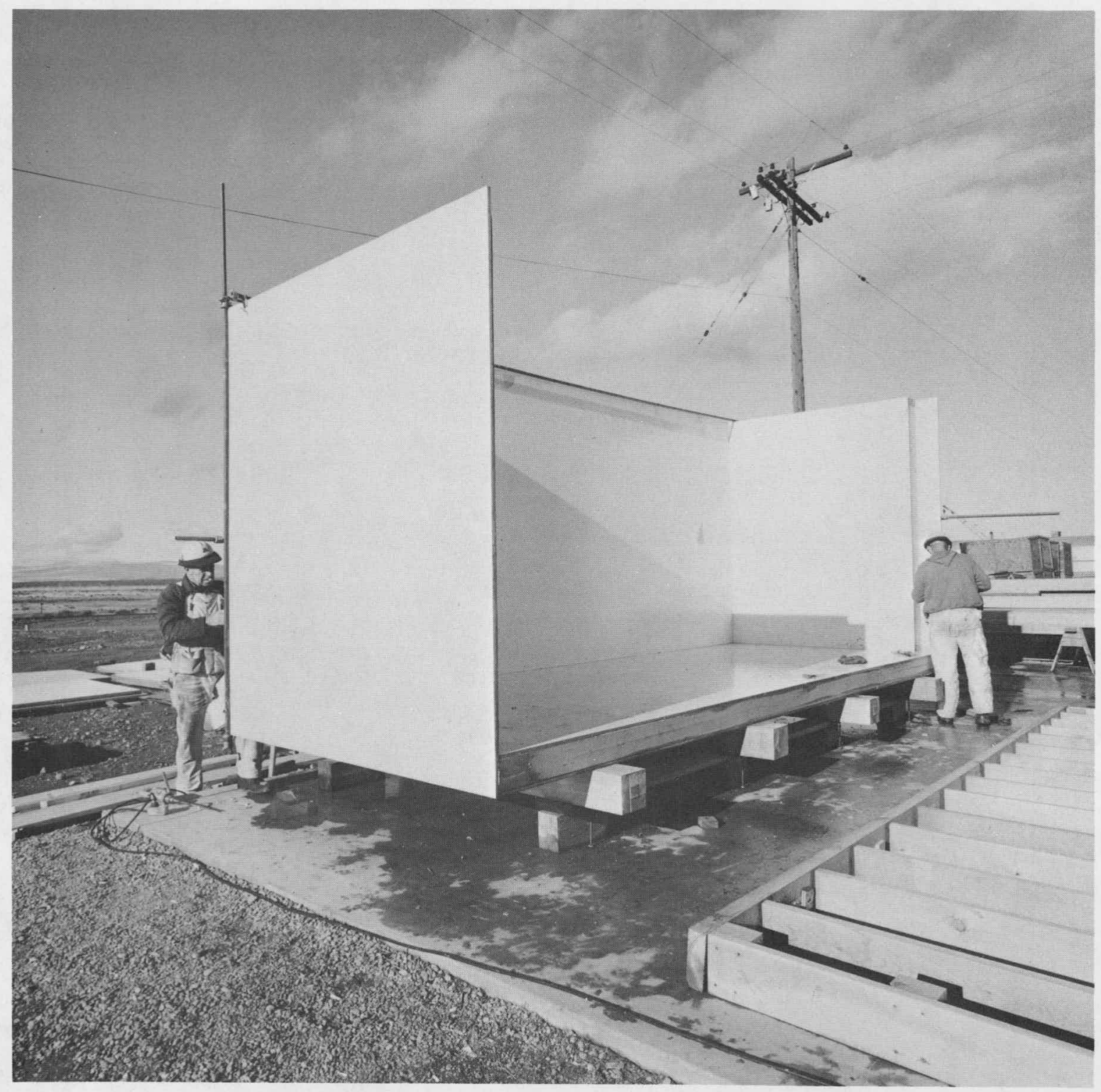

FIGURE 19 


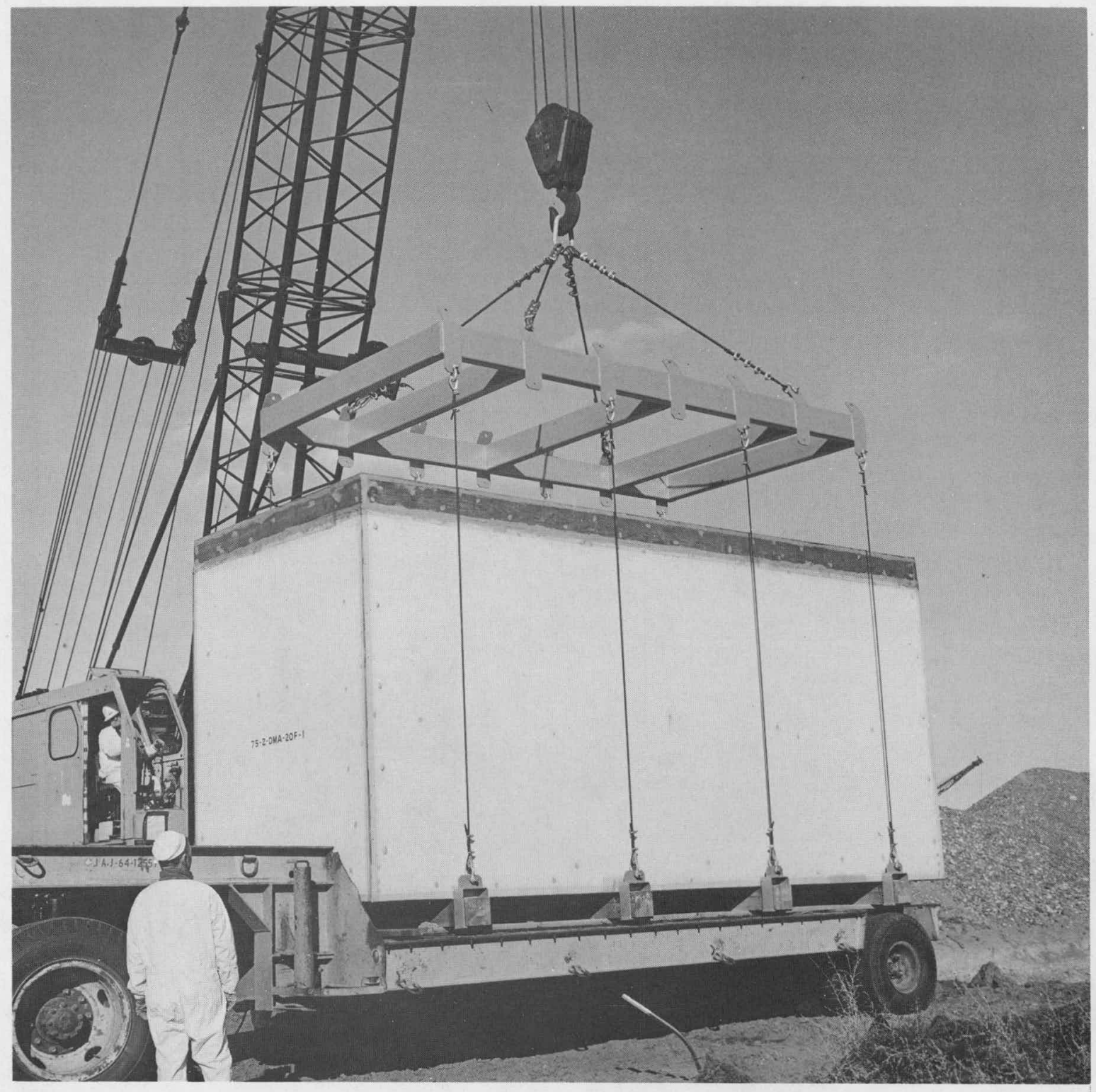

FIGURE 20 


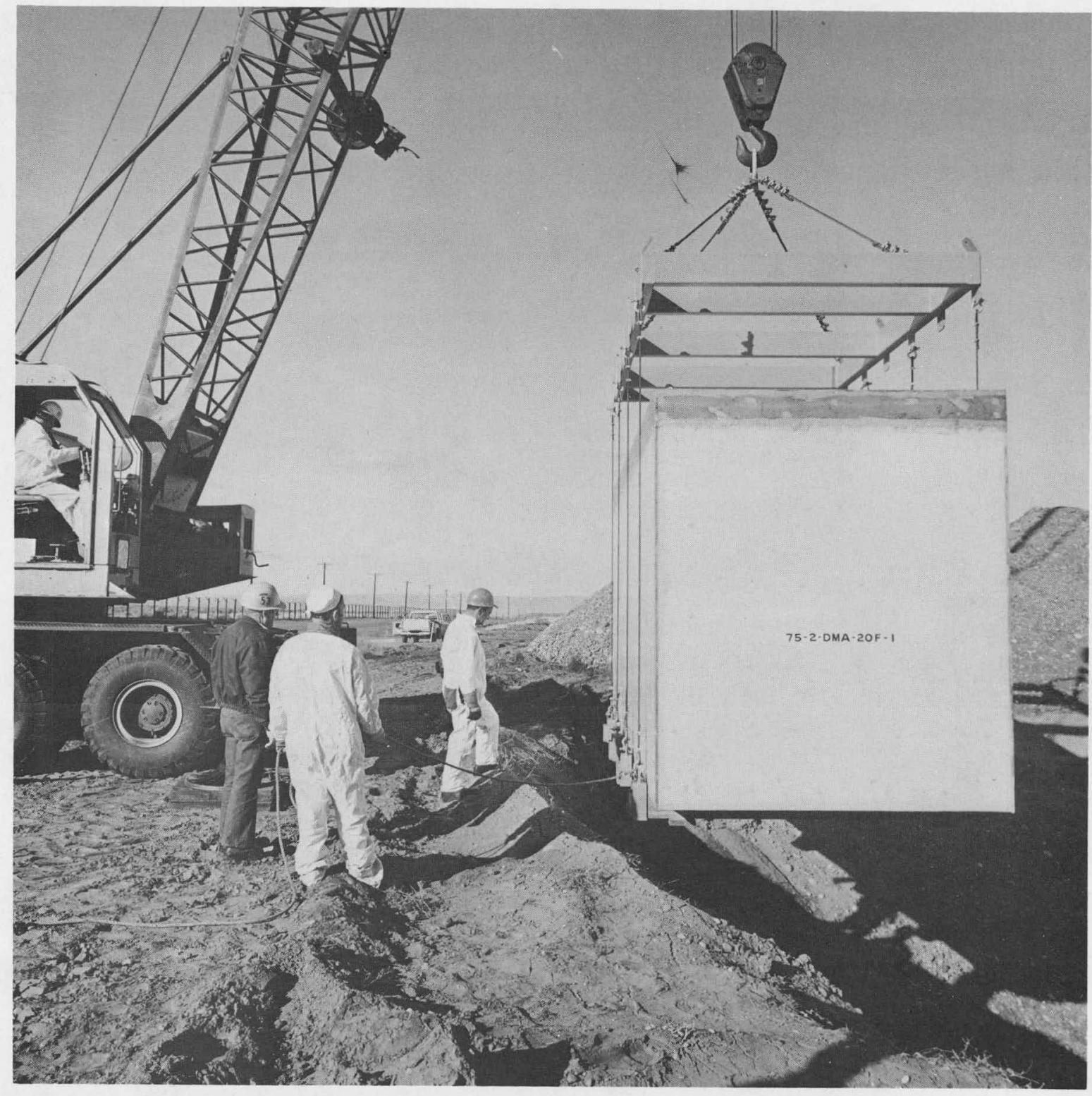

FIGURE 21 


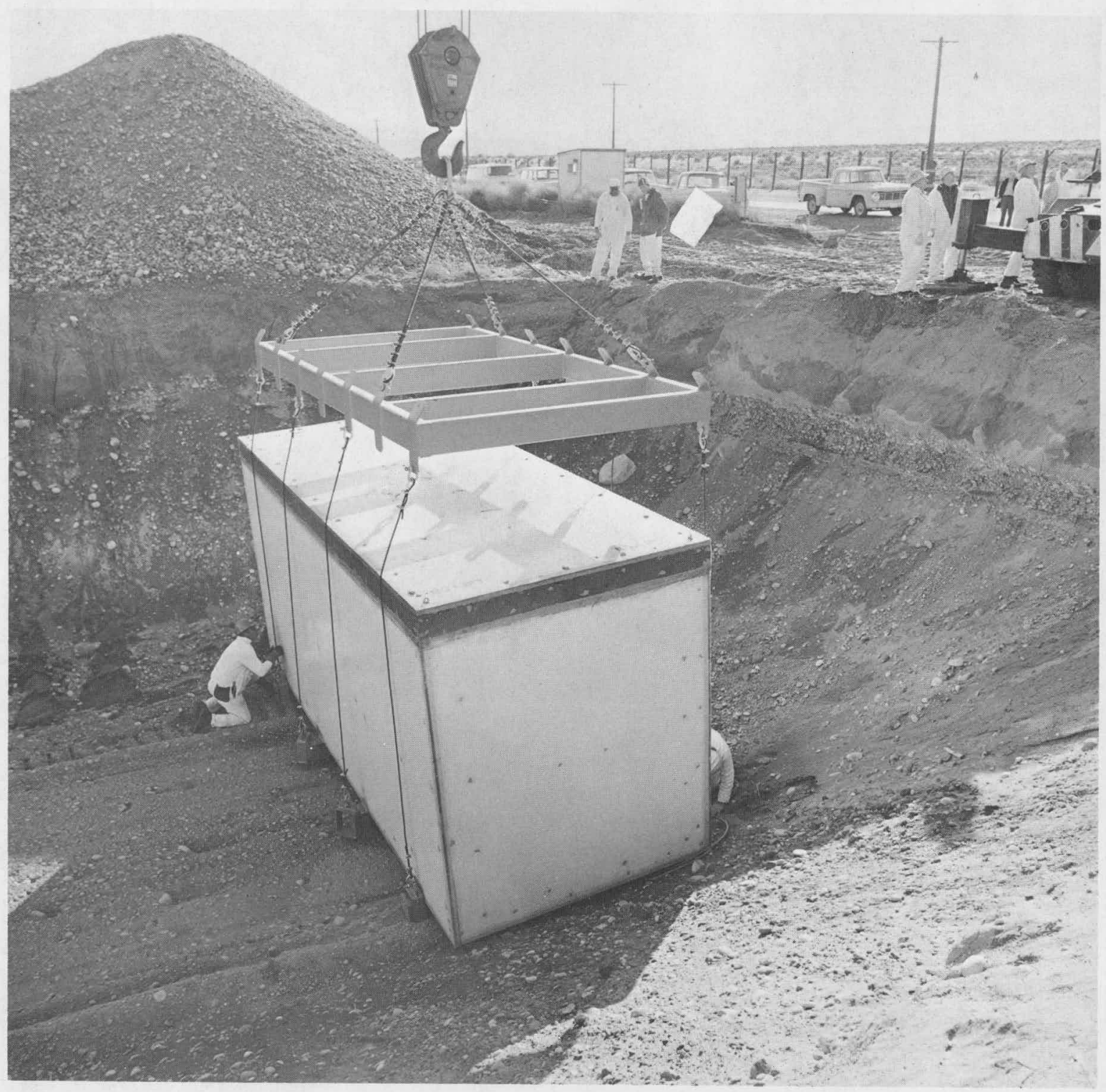

FIGURE 22 